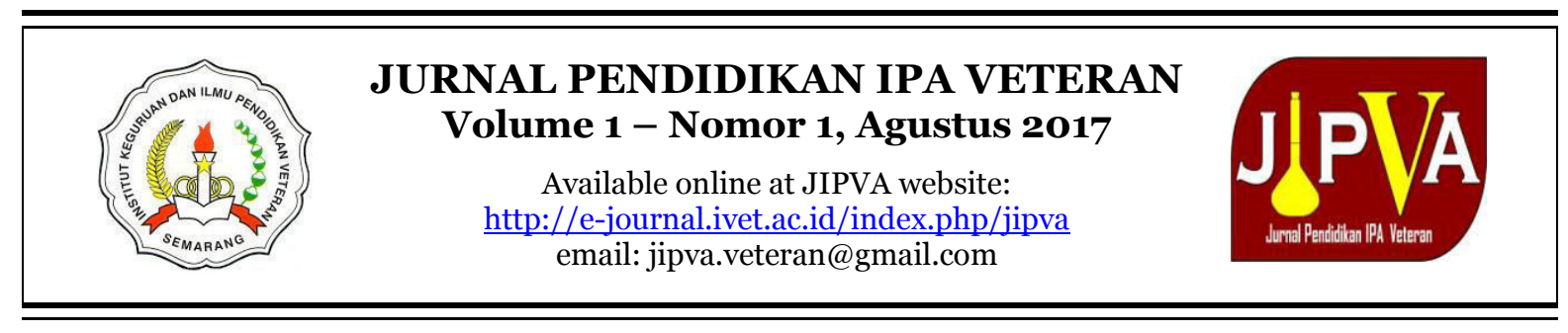

\title{
IMPLEMENTASI KURIKULUM 2013 PADA PEMBELAJARAN KIMIA DI SMKN 1 TELUK KUANTAN
}

\author{
Rosa Murwindra, Nofri Yuhelman, Dwi Putri Musdansi \\ Jurusan Pendidikan Kimia Fakultas Tarbiyah dan Keguruan \\ Universitas Islam Kuantan Singingi, Teluk Kuantan \\ e-mail: rosamurwindra@gmail.com
}

\begin{abstract}
Abstrak
Tujuan penelitian ini adalah untuk mendeskripsikan implementasi kurikulum 2013 pada pembelajaran kimia di SMKN 1 Teluk Kuantan. Penelitian ini merupakan penelitian deskriptif kualitatif dan pengumpulan data digunakan purposive sampling. Metode pengumpulan data dilakukan dengan wawancara, observasi, dokumentasi dan angket. Teknik analisis data yang digunakan dalam penelitian ini adalah pengumpulan data, reduksi data, sajian data dan penarikan kesimpulan. Berdasarkan hasil penelitian dapat disimpulkan bahwa secara umum implementasi kurikulum 2013 sudah dilaksanakan meskipun belum optimal karena adanya beberapa kendala yang akan terus diatasi agar implementasi kuriklum 2013 menjadi lebih baik.
\end{abstract}

Kata kunci: Peserta didik, Pembelajaran Kimia, Kurikulum 2013

\section{IMPLEMENTATION OF CURRICULUM 2013 IN CHEMIST TEACHING LEARNING PROCESS AT SMK NEGERI 1 TELUK KUANTAN}

\begin{abstract}
The purpose of this research is to describe the implementation of curriculum $2013 \mathrm{in}$ chemist teaching learning process at SMK Negeri 1 Teluk Kuantan. This research is kind of description qualitative research, to collect the data this research using purposive sampling. In order to collect the data this research is using interview, observation, documentation, and questionnaire. Data analysis technique which used in this research are data collection, data reduction, data display, and conclusion drawing. Based on the result of the research, it can be concluded that generally curriculum 2013 already applied, even though it does not run well get because of some problem which will be solved in order to improve the implementation of curriculum 2013.
\end{abstract}

Keywords: Students, chemistry learning, and curriculum 2013 


\section{PENDAHULUAN}

Pendidikan dapat berlangsung
secara formal maupun non-formal. Pendidikan formal sebagaimana yang dirumuskan di dalam Undang-undang Nomor 2 Tahun 1989 Tentang Sistem Pendidikan Nasional, yaitu "Pendidikan di sekolah yang teratur, sistematis, mempunyai jenjang serta terbagi dalam waktu tertentu yang berlangsung dari taman kanak-kanak sampai perguruan tinggi”. Program pendidikan dan pengetahuan belajar yang dihayati oleh peserta didik harus diarahkan untuk dapat dikembangkan dengan baik supaya mereka menguasai berbagai kemampuan yang bermanfaat dalam menghadapi tantangan dan tuntutan masyarakat di masa depan (Minhaji, 2013).

Undang-undang Sistem Pendidikan Nasional Nomor 20 Tahun 2003 pasal 3 tentang Sistem Pendidikan Nasional menyebutkan bahwa Pendidikan nasional berfungsi mengembangkan dan membentuk watak serta peradaban bangsa yang bermanfaat dalam rangka mencerdaskan kehidupan bangsa, bertujuan untuk berkembangnya potensi peserta didik agar menjadi manusia yang beriman dan bertaqwa kepada Tuhan Yang Maha Esa, berakhlak mulia, sehat, berilmu, cakap, kreatif, mandiri dan menjadi warga negara demokratis serta bertanggungjawab. Dengan dirumuskan fungsi dan tujuan pendidikan nasional tersebut, menjadi tolak ukur merumuskan Standar Nasional Pendidikan. Standar Nasional Pendidikan berfungsi sebagai dasar perencanaan, pelaksanaan dan pengawasan pendidikan dalam rangka mewujudkan pendidikan nasional yang bermutu.

Perwujudan pendidikan dalam proses belajar-mengajar secara praktis di tentukan oleh kurikulum. Kurikulum adalah seperangkat rencana dan pengaturan mengenai tujuan, isi, dan bahan pelajaran serta cara yang digunakan sebagai pedoman penyelenggaraan kegiatan pembelajaran untuk mencapai tujuan pendidikan tertentu. Kurikulum disusun secara nasional di Indonesia, dengan tujuan agar setiap warga negara, dimanapun ia bersekolah, mempunyai kesempatan memperoleh kompetensi yang sama. Sistem pendidikan nasional di Indonesia telah mengalami sepuluh kali perubahan kurikulum, dalam rangka menghadapi berbagai tantangan yang timbul seiring dengan perkembangan zaman, ilmu pengetahuan dan teknologi, tingkat kecerdasan peserta didik, kultur, sistem nilai dan kebutuhan masyarakat.

Kurikulum 2013 merupakan kurikulum berbasis kompetensi yang dikembangkan dari kurikulum tahun 2004 dan KTSP 2006 untuk merespon berbagai tantangan internal dan eksternal bangsa. Dalam menghadapi berbagai tantangan tersebut, maka titik tekan pengembangan Kurikulum 2013 adalah penyempurnaan pola pikir, penguatan tata kelola kurikulum, pendalaman dan perluasan materi, penguatan proses pembelajaran, dan penyesuaian beban belajar agar dapat menjamin kesesuaian antara yang diinginkan sekolah dengan yang dihasilkan. Pengembangan kurikulum perlu disesuaikan dengan kemajuan ilmu pengetahuan, teknologi, dan seni budaya serta perubahan masyarakat pada tataran lokal, nasional, regional, dan global di masa depan.

Salah satu sekolah yang telah menerapkan kurikulum 2013 adalah SMKN 1 Teluk Kuantan. Berdasarkan hasil wawancara dengan salah seorang 
Rosa Murwindra, Nofri Yuhelman, Dwi Putri M.

guru kimia, Ibu Beti Sri Ramadani, S.Pd diperoleh informasi bahwa pelaksanaan kurikulum 2013 di SMKN 1 Teluk Kuantan telah berjalan mulai dari tahun ajaran 2013/2014 dan sudah melakukan persiapan untuk mengimplemetasikan kurikulum 2013. Hal ini bisa dilihat dari sarana dan prasarana yang memadai, fasilitas dan sumber belajar yang mendukung serta beberapa usaha yang sudah di tempuh guru seperti mengikuti berbagai pelatihan tentang kurikulum 2013 khususnya pada pembelajaran kimia karena banyak sekali persiapan-persiapan yang harus dilakukan terkait dengan implementasi kurikulum 2013 yakni persiapan dalam proses administrasi pembelajaran.

Secara keseluruhan, hal tersebut tidak terlepas dari hambatan-hambatan dalam proses pelaksanaan pembelajaran. Salah satu hambatan tersebut adalah kurangnya pemahaman peserta didik terhadap materi pelajaran, meskipun materinya sudah dijelaskan secara berulang-ulang dan dengan metode yang berbeda pula. Selain itu, materi KTSP juga berbeda dengan kurikulum 2013. Hal ini sesuai dengan penelitian yang pernah dilakukan oleh Alawiyah (2013) tentang dampak implementasi kurikulum 2013 bahwa adanya ketidaksesuaian antara isi buku dengan materi dan perkembangan kognitif peserta didik dan kurikulum 2013 dapat berjalan dengan baik apabila didukung dengan sarana dan prasarana yang mencukupi atau memadai (Nuruzzaman, 2015). Oleh karena itu, perlu dilakukan penelitian untuk mengetahui bagaimana implementasi kurikulum 2013 pada pembelajaran kimia di SMKN 1 Teluk Kuantan Kabupaten Kuantan Singingi, yang dimulai dari tahap sosialisasi sampai proses pelaksanaan kurikulum 2013.

Mata pelajaran kimia mempunyai karakteristik sama dengan IPA. Karakteristik tersebut adalah objek ilmu kimia, cara memperoleh, serta kegunaannya. Kimia merupakan ilmu yang pada awalnya diperoleh dan dikembangkan berdasarkan percobaan (induktif) namun pada perkembangan selanjutnya kimia juga diperoleh dan dikembangkan berdasarkan teori (deduktif). Oleh sebab itu, mata pelajaran kimia di SMK mempelajari segala sesuatu tentang zat meliputi komposisi, struktur dan sifat, perubahan, dinamika dan enegetika zat yang melibatkan keterampilan dan penalaran (Dirjen Dikmen 2014).

Pembelajaran kimia dilakukan dengan memberikan metode pembelajaran yang tepat untuk tiap-tiap materi. Hal ini dikarenakan pada tiap-tiap materi dalam kimia memiliki karakteristik tersendiri. Beberapa teknik yang dapat diterapkan dalam pembelajaran kimia disesuaikan dengan sifat-sifat khas dari ilmu kimia, yakni: 1) mempelajari ilmu kimia dengan konsep, 2) dari materi yang mudah ke sukar, 3) menggunakan berbagai teknik menghafal, menyelesaikan soal, penguasaan konsep, menguasai aturan kimia, penyelesaian masalah dilaboratorium, 4) mengaitkan dengan kehidupan sehari-hari.

Dengan demikian, peran guru kimia pun semakin meningkat karena dituntut untuk merencanakan metode pembelajaran yang menarik dan sesuai 
sehingga dapat membantu peserta didik lebih mudah memahami materi yang diajarkan. Disamping itu, proses pembelajaran yang tepat akan meningkatkan perhatian dan motivasi peserta didik sehingga tidak cepat merasa bosan dalam belajar kimia serta tercipta suasana belajar yang menyenangkan baik secara fisik maupun psikologis. Apabila hal tersebut tercapai, maka peserta didik akan lebih siap dalam menerima pelajaran kimia (Hamzah, 2007).

Permasalahan pada penelitian ini adalah bagaimana implementasi kurikulum 2013 pada pembelajaran kimia di SMKN 1 Teluk Kuantan. Adapun tujuan pada penelitian ini yaitu untuk mendeskripsikan implementasi kurikulum 2013 pada pembelajaran kimia di SMKN 1 Teluk Kuantan. Manfaat penelitian yakni segi guru memberikan kontribusi dalam meningkatkan dan menyempurnakan implementasi kurikulum 2013 pada pembelajaran kimia di SMKN 1 Teluk Kuantan. Segi Kepala Sekolah, memberikan motivasi dalam memberikan layanan dan bimbingan serta bantuan kepada guru dalam pelaksanaan kurikulum 2013. Segi UNIKS, sebagai sumbangan pemikiran bagi Akademika Jurusan Pendidikan Kimia pada Fakultas Tarbiyah dan Keguruan Universitas Islam Kuantan Singingi (UNIKS) dalam menambah khasanah keilmuan yang ada hubungannya tentang proses belajar-mengajar.

\section{METODE}

\section{Jenis Penelitian}

Penelitian ini termasuk penelitian lapangan (field research) yang bersifat kualitatif.

\section{Waktu dan Tempat Penelitian}

Penelitian ini dilaksanakan pada bulan September 2016 sampai dengan
November 2016 dan tempat pelaksanaannya yakni di SMKN 1 Teluk Kuantan.

\section{Target/Subjek Penelitian}

Pengambilan sampel mengacu kepada teknik purposive sampling. Untuk subjek yang diambil peneliti adalah:

a. Peserta didik kelas X SMKN 1 Teluk Kuantan

b. Bapak/Ibu Guru yang mengampu mata pelajaran kimia.

c. Waka Kurikulum

\section{Prosedur}

Penelitian ini merupakan penelitian deskriptif dengan menggambarkan pelaksanaan pembelajaran kimia apa adanya di SMKN 1 Teluk Kuantan.

\section{Teknik Pengumpulan Data}

Wawancara

Dalam metode wawancara ini peneliti memperoleh keterangan tentang implementasi kurikulum 2013 dalam pembelajaran kimia. Adapun wawancara ini dilakukan pada guru kimia, peserta didik kelas X dan Waka Kurikulum.

Observasi

Setelah diperoleh hasil wawancara, dilanjutkan dengan mengadakan observasi. Dalam hal ini peneliti mengadakan observasi dengan kegiatan-kegiatan peserta didik dalam proses pembelajaran kimia, kegiatan-kegiatan guru kimia dan sekolah lakukan untuk mendukung implementasi kurikulum 2013.

Angket

Angket dalam hal ini berisikan
daftar pertanyaan yang disusun
berdasarkan permasalahan pokok
penelitian yang diajukan kepada responden
yakni para guru yang akan memberikan
jawaban sesuai dengan alternatif jawaban
yang telah disediakan.
Dokumentasi


Rosa Murwindra, Nofri Yuhelman, Dwi Putri M.

Metode dokumentasi ini digunakan peneliti untuk memperoleh data mengenai keadaaan dan kegiatan-kegiatan peserta didik, guru dan sekolah serta keadaan sarana dan prasarana sekolah dan lain-lain yang terkait kurikulum 2013.

\section{Validitas Data}

Untuk menguji validitas data peneliti menggunakan teknik triangulasi data, yakni model triangulasi teknik dan triangulasi sumber. Triangulasi teknik dengan menggunakan teknik pengumpulan data yang berbeda untuk mendapatkan data dari sumber yang sama yaitu seperti wawancara, observasi dan dokumentasi kepada masing-masing guru kimia. Triangulasi sumber adalah salah satu teknik pengumpulan data dengan berbagai macam sumber data yaitu wawancara mendalam dengan guru kimia (Sugiyono, 2008).

\section{Teknik Analisis Data}

Setelah data dan informasi yang dibutuhkan terkumpul, maka untuk mengetahui pelaksanaan pembelajaran dilakukan pendeskripsian dan analisis data secara deskriptif. Analisis yang dikembangkan oleh Miles dan Hubberman (1994) dengan tiga langkah:

\section{Reduksi data}

Reduksi data merupakan kegiatan pemilihan, penyederhanaan dan transformasi data yang kasar yang muncul dari catatan tertulis di lapangan, sehingga menjadi lebih fokus sesuai dengan objek penelitian. Reduksi data berlangsung selama proses penelitian sampai tersusunnya laporan akhir penelitian.

\section{Penyajian data}

Penyajian data sekumpulan informasi yang memberikan kemungkinan adanya penarikan kesimpulan dan pengambilan tindakan. Penyajian data dalam penelitian ini merupakan gambaran seluruh informasi tentang pelaksanaan pembelajaran kimia berdasarkan kurikulum 2013.

Penarikan kesimpulan

Penarikan kesimpulan atau verifikasi merupakan suatu kegiatan konfigurasi utuh. Setelah analisis dilakukan, maka dapat disimpulkan masalah yang telah ditatakan oleh peneliti. Dari hasil pengelolaan dan penganalisisan data ini kemudian diberi interpretasi terhadap masalah yang akhirnya digunakan oleh penulis sebagai dasar untuk menarik kesimpulan. Peneliti dapat melihat apa yang diteliti dan menemukan kesimpulan yang benar mengenai objek penelitian. Kesimpulan-kesimpulan juga diverifikasi selama penelitian berlangsung.

\section{HASIL DAN PEMBAHASAN \\ Sosialisasi Kurikulum 2013}

Secara kualitatif, SMKN 1 Teluk Kuantan sudah menerima sosialisasi kurikulum 2013 yang diadakan oleh pemerintah. Semua elemen yang ada di SMKN 1 Teluk Kuantan seperti guru bidang studi dan tenaga kependidikan sudah menerima sosialisasi kurikulum tersebut pada awal-awal tahun 2013. Sebagian besar guru juga sudah mengikuti pelatihan dan workshop baik yang diadakan oleh SMKN 1 Teluk Kuantan, Dinas Pendidikan Kabupaten Kota Kuantan Singingi maupun Dinas Pendidikan Tingkat Propinsi. SMKN 1 Teluk Kuantan juga membuat kluster dimana mereka sendiri sebagai sekolah induk dengan mengadakan kegiatan in-onin training. Hal ini sesuai dengan pendapat 
Mulyasa (2013) bahwa salah satu kunci sukses yang mendorong keberhasilan kurikulum 2013 adalah sosialisasi.

Berikut hasil dokumetasi peneliti saat wawancara dengan Ibu Teti Indriani, S.Si selaku mewakili Waka kurikulum dapat dilihat pada Gambar 1.

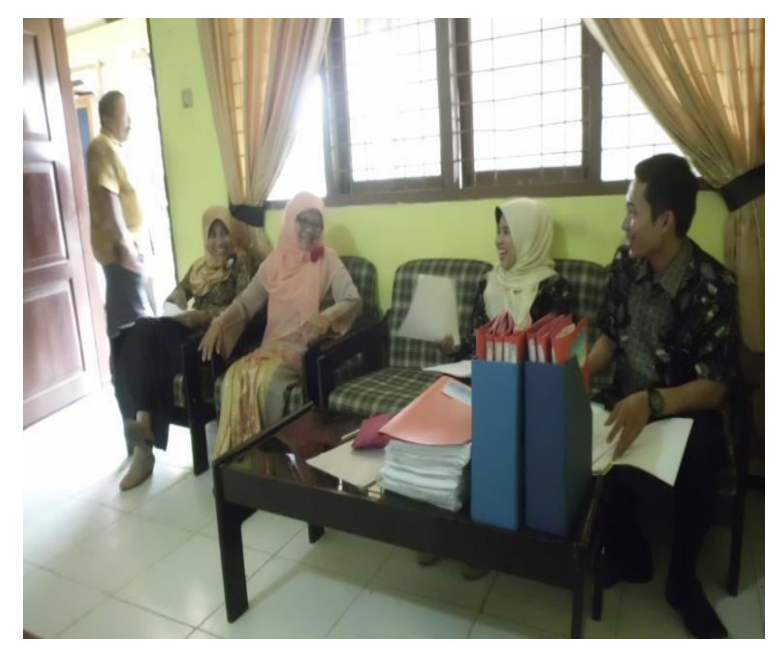

Gambar 1. Foto Peneliti saat wawancara dengan Ibu Teti Indriani, S.Si

Sosialisasi dalam implementasi kurikulum penting dilakukan, agar semua pihak yang terlibat dalam implementasinya di lapangan paham dengan perubahan yang harus dilakukan sesuai dengan tugas pokok dan fungsinya masing-masing, sehingga mereka memberikan dukungan terhadap perubahan kurikulum yang dilakukan. Dalam hal ini seharusnya pemerintah mengembangkan grand design yang jelas dan menyeluruh, agar konsep kurikulum yang diimplementasikan dapat dipahami oleh para pelaksana secara utuh, tidak ditangkap secara parsial, keliru atau salah paham.

Sosialisasi kurikulum perlu dilakukan terhadap berbagai pihak yang terkait dalam implementasinya, serta terhadap seluruh warga sekolah, bahkan terhadap masyarakat dan orang tua peserta didik. Sosialisasi ini penting, terutama agar seluruh warga sekolah mengenal dan memahami visi dan misi sekolah, serta kurikulum yang diimplementasikan. Sosialisasi dapat dilakukan oleh jajaran pendidikan di pemerintah pusat maupun pemerintah daerah yang bergerak dalam bidang pendidikan (Dinas Pendidikan dan Kebudayaan) secara proporsional dan profesional.

Perencanaan Pembelajaran kimia. Perencanaan adalah aktivitas pengambilan keputusan tentang apa yang akan dicapai, tindakan apa yang akan diambil dalam rangka pencapaian tujuan atau sasaran tersebut, dan siapa yang akan melaksanakan tujuan (Burhanuddin, 1994).

Adapun perencanaan pembelajaran kimia di SMKN 1 Teluk Kuantan, guru sudah menyusun perangkat pembelajaran seperti pengembangan silabus, program tahunan, pogram semester dan pengembangan rencana pelaksanaan pembelajaran (RPP), meskipun masih ada kendala-kendala yang dihadapi di dalam pelaksanaannya. Hal ini sesuai dengan pengembangan kurikulum 2013 yaitu mengenai penyusunan RPP dengan berdasar prinsip-prinsip yang tertulis pada Permendikbud No. 65 Tahun 2013 tentang standar proses pendidikan dasar dan menengah dan merujuk pada silabus yang dibuat pemerintah dalam mengimplementasikan kurikulum 2013 terhadap RPP guru dapat mengaitkan dan memadukan antara kompetensi dasar, materi pembelajaran, kegiatan pembelajaran, indikator pencapaian kompetensi, penilaian, sumber belajar serta penerapan teknologi informasi dan komunikasi yang mereka rancang dalam satu keutuhan pengalaman belajar. 
Rosa Murwindra, Nofri Yuhelman, Dwi Putri M.

Adapun Format silabus kurikulum 2013 di SMKN 1 Teluk Kuantan dapat dilihat pada Gambar 2 berikut.

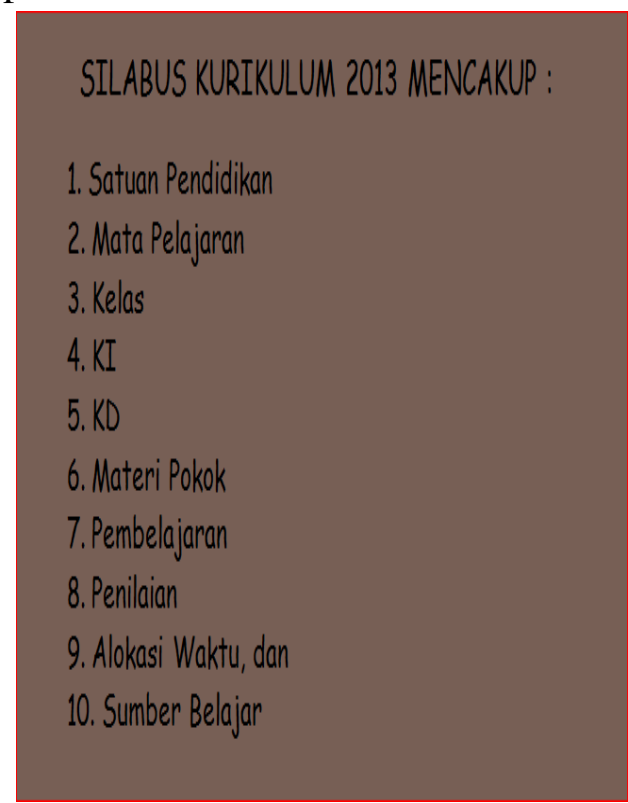

Gambar 2. Format silabus kurikulum 2013 di SMKN 1 Teluk Kuantan

Sementara itu, format RPP kurikulum 2013 di SMKN 1 Teluk Kuantan yang disusun oleh guru kimia secara umum meliputi: kelas/semester, materi pelajaran, alokasi waktu, jumlah pertemuan, kompetensi inti (KI), kompetensi dasar (KD), indikator pencapaian kompetensi (IPK), tujuan pembelajaran, materi pembelajaran, metode pembelajaran, kegiatan

pembelajaran, sumber belajar/ bahan ajar/ alat dan penialaian. Format RPP kurikulum 2013 di SMKN 1 Teluk Kuantan dapat dilihat pada Gambar 3.

Berdasarkan RPP hasil penelitian, dapat dilihat kesesuaian antara komponen RPP yang telah dibuat oleh guru dengan komponen RPP berdasarkan Kurikulum 2013, yang mencakup: 1) data sekolah, mata pelajaran, kelas/semester; 2) materi pokok; 3) alokasi waktu; 4) KI, KD dan indikator pencapaian kompetensi, serta tujuan pembelajaran; 5) materi pembelajaran, metode pembelajaran; 6) media, alat dan sumber belajar; 7) langkahlangkah kegiatan pembelajara; dan 8) penilaian.

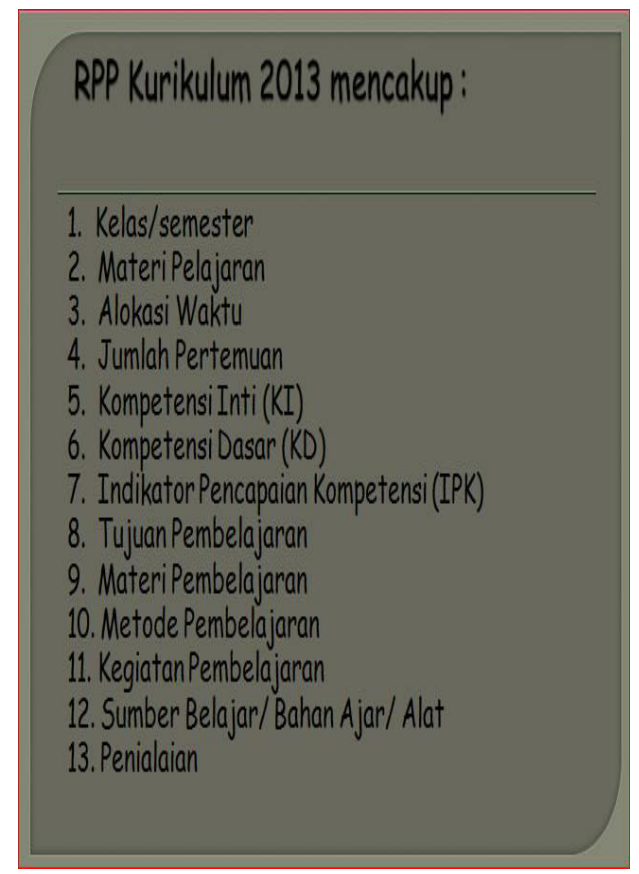

Gambar 3. Format RPP kurikulum 2013 di SMKN 1 Teluk Kuantan

Pentingnya perangkat pembelajaran ialah sebagai panduan, tolok ukur, peningkatan profesionalisme dan mempermudah penyampaian materi. Perangkat pembelajaran meliput kalender pendidikan, alokasi waktu pembelajaran, program tahunan, program semester, silabus, RPP, jurnal harian mengajar dan penilaian.

Silabus dan Rencana Pelaksanaan Pembelajaran menunjukkan bahwa guru membuat silabus pengajaran yang dilanjutkan dengan pembuatan perencanaan pengajaran sebelum memulai kegiatan pengajaran. Pada pembuatan perencanaan pembelajaran diperlukan pedoman pembuatan rencana pengajaran 
yang berupa referensi-referensi penunjang terhadap materi pelajaran yang akan disampaikan serta mengacu pada kurikulum. Jadi, dalam KI dan KD dalam menyusun RPP mengacu pada kurikulum.

Guru sebagai salah satu sumber belajar berkewajiban menyediakan lingkungan belajar yang kreatif bagi kegiatan belajar anak didik dikelas. Salah satu kegiatan yang harus guru lakukan dalam melakukan pemilihan dan penentuan metode yang akan dipilih untuk mencapai tujuan pembelajaran. Sumber belajar atau bahan ajar merupakan informasi, alat dan teks yang diperlukan guru untuk perencanaan dan penelaahan implementasi pembelajaran (Majid, 2007).

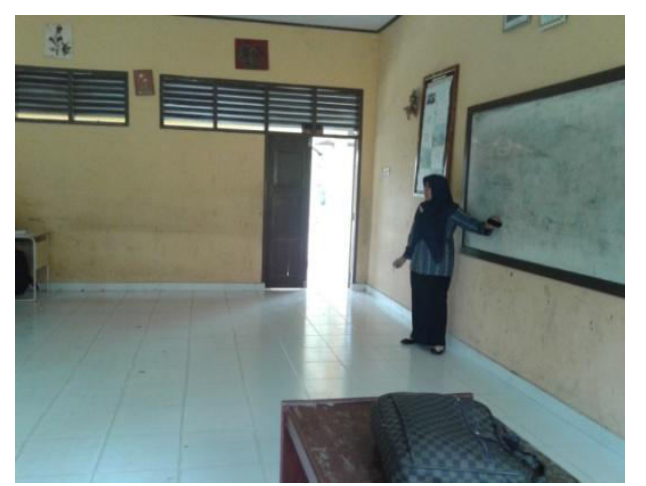

Gambar 4. Foto guru menjelaskan materi lambang atom/unsur di kelas $\mathrm{X}$ TGB (Teknik Gambar Bangunan)

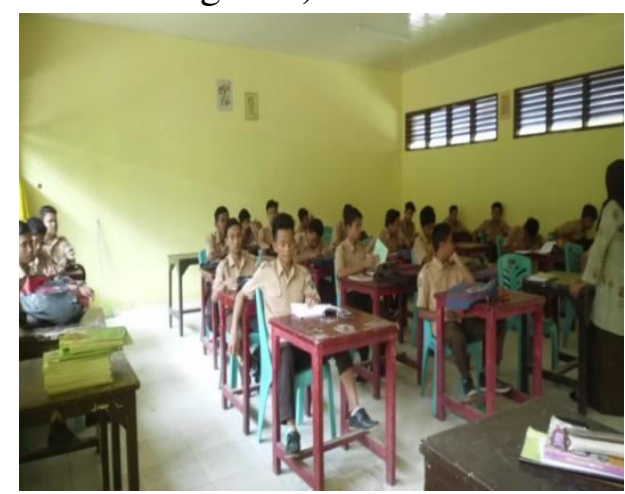

Gambar 5. Foto peserta didik kelas XI TITL (Teknik Instalasi Tenaga Listrik) mendengarkan penjelasan dari guru
Adapun pelaksanaan pembelajaran kimia di SMKN 1 Teluk Kuantan, guru kimia dalam penyampaian materi terkadang tidak menyesuaikan dengan silabus dan RPP yang telah direncanakan. Dalam penyampaian materi untuk mewujudkan tujuan pembelajaran yang harapkan guru masih menggunakan strategi pembelajaran yang dominan dipengaruhi oleh KTSP. Padahal, untuk mencapai pembelajaran yang berkualitas dan peserta didik dapat menerima, memahami dan tertarik pada materi seharusnya guru memanfaatkan media agar tujuan dari peningkatan mutu pembelajaran kimia dapat tercapai. Berdasarkan hal tersebut menunjukkan bahwa, guru kimia SMKN 1 Teluk Kuantan belum sepenuhnya mengimplementasikan Kurikulum 2013 dalam hal pelaksanaan pembelajaran yang sesuai dengan pengembangan Kurikulum 2013, yaitu mengenai pembelajaran peserta didik aktif, mandiri, kritis, pembelajaran berbasis pemecahan masalah, pola pembelajaran berbasis tim, penggunaan karakteristik pembelajaran yang disesuaikan dengan karakteristik kompetensi dan penerapan pembelajaran discovery learning yang terangkum di dalam kegiatan pendahuluan, kegiatan inti dan kegiatan penutup yang dilaksanakan selama kegiatan belajar mengajar berlangsung.

Sistem Evaluasi Pembelajaran Kimia. Evalusi pembelajaran merupakan proses penaksiran terhadap kemajuan, pertumbuhan dan perkembangan anak didik dalam rangka untuk mencapai tujuan pendidikan. Pelaksanaan kegiatan evaluasi pembelajaran ditunjukkan pada karakteristik siswa dengan menggunakan tolok ukur tertentu. Karakteristikkarakteristik tersebut dalam ruang lingkup 
Rosa Murwindra, Nofri Yuhelman, Dwi Putri M.

kegiatan belajar mengajar dan evaluasi. Kegiatan pembelajaran dan evaluasi juga harus mengacu pada domain hasil belajar, yaitu kognitif (pengetahuan dan intelektual), afektif (sikap), dan psikomotorik (ketrampilan dan tindakan). Hal tersebut dievaluasi secara kinerja, portofolio, lisan, tulis dan observasi. Dengan demikian mengevaluasi disini menentukan apakah kemampuan peserta didik telah sesuai dengan tujuan instruksional yang telah dirumuskan atau belum. Penggunaan teknik evaluasi juga harus berpedoman pada indikator pencapaian yang telah dibuat guru dan silabus materi. Dengan adanya indikatorindikator tersebut guru dapat merumuskan pertanyaan soal baik lisan, tulisan secara sistematis dan tetap terarah pada indikator yang ada (Arifin, 2011).

Berikut ditampilkan hasil dokumentasi yang peneliti peroleh pada saat pelaksanaan penilaian formatif yang dilaksanakan di kelas X TGB, oleh Ibu Dra. Ermalina pada materi lambang atom/unsur. Adapun foto tersebut dapat dilihat pada Gambar 6.

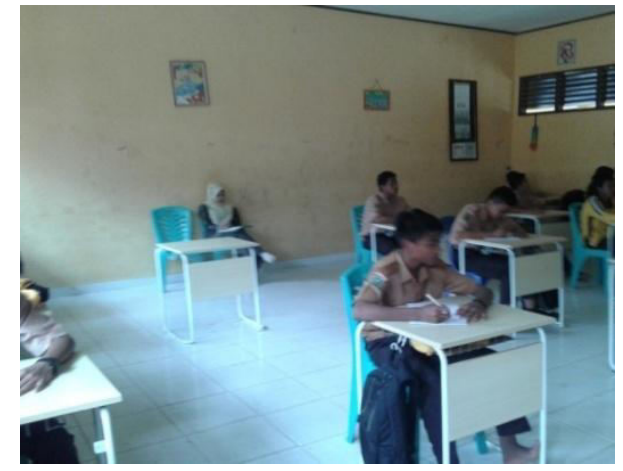

Gambar 6. Foto Pelaksanaan penilaian formatif

Berdasarkan hasil penelitian menunjukkan bahwa teknik evaluasi yang digunakan oleh guru kimia di SMKN 1 Teluk Kuantan menggunakan teknik penilaian Formatif dan Sumatif. Hal ini sesuai dengan pendapat Arifin (2011) bahwa penilaian formatif berfungsi untuk memantau dan penilaian sumatif bertujuan mengetahui sudah sejauh mana peserta didik itu sudah terbentuk sudah sesuai dengan tujuan pembelajaran yag telah ditentukan setelah mereka mengikuti suatu proses pembelajaran dalam rangka waktu.

\section{SIMPULAN DAN SARAN}

\section{Simpulan}

Secara kualitatif, semua elemen yang ada di SMKN 1 Teluk Kuantan sudah menerima sosialisasi kurikulum 2013 yang diadakan oleh pemerintah. Sebagian besar guru sudah mengikuti pelatihan dan workshop baik yang diadakan oleh SMKN 1 Teluk Kuantan, Dinas Pendidikan Kabupaten Kota Kuantan Singingi maupun Dinas Pendidikan Tingkat Propinsi. Dalam perencanaan pembelajaran, Secara keseluruhan guru kimia SMKN 1 Teluk Kuantan sudah menyusun perangkat pembelajaran seperti pengembangan silabus, program tahunan, pogram semester dan pengembangan rencana pelaksanaan pembelajaran (RPP), meskipun masih ada kendala-kendala yang dihadapi di dalam pelaksanaannya. Dalam proses pelaksanaan pembelajaran, guru kimia sudah berusaha menjalankan kurikulum 2013 meskipun dalam penyampaian materi terkadang tidak menyesuaikan dengan silabus dan RPP yang telah direncanakan dikarenakan beberapa kendala. Dalam sistem evaluasi, Guru kimia di SMKN 1 Teluk Kuantan mempunyai perencanaan, pelaksanaan dan mengolah data dalam setiap pembelajaran. Adapun teknik evaluasi yang digunakan adalah teknik penilaian Formatif dan Sumatif. 


\section{Saran}

Bagi guru kimia disarankan untuk mengembangkan berbagai metode pendekatan dalam pelaksanaan pembelajaran seperti metode pendekatan scientific approach, project based learning, discovery learning yang sesuai dengan kurikulum 2013 dan juga disarankan agar berdialog dan berdiskusi dengan rekan-rekan guru kimia yang tergabung dalam MGMP, berkaitan dengan seluruh kendala implementasi kurikulum 2013.

\section{DAFTAR PUSTAKA}

Alawiyah, faridah. 2013. Dampak Implementasi Kurikulum 2013 Terhadap Guru. P3DI. Setjen DPR RI. Jakarta.

Arifin, Z. 2011. Penelitian pendidikan metode dan paradigma Baru. Bandung : Remaja Rosdakarya.

Burhanudin, 1994. Analisis Administrasi dan Manajemen Pendidikan Dalam Kepemimpinan Pendidikan. Jakarta: Depdikbud.

Direktorat Pembinaan SMA-Ditjen Pendidikan Menengah. 2014. Pembelajaran Kimia Melalui Pendekatan Saintifik. Jakarta.

Hamzah, B. Uno. 2007. Metode Penelitian dan Teori Komunikasi. Malang: UMM Press.

Majid, A., 2007., Perencanaan Pembelajaran. Bandung: PT Remaja Rosdakarya.

Mattew B, Milles and Hubberman M. A. 1994. Qualitative Data Analysis. California : Sage Publication, Inc.

Menteri Pendidikan dan Kebudayaan Republik Indonesia. 2013. Peraturan Menteri Pendidikan dan Kebudayaan Republik Indonesia Nomor 65Tahun 2013 tentang Standar Proses Pendidikan Dasar dan Menengah. Jakarta.
Minhaji, A. 2013. Tradisi Akademik di Perguruan Tinggi. Yogyakarta : SUKA Press.

Mulyasa, H.E. 2013. Pengembangan dan Implementasi Kurikulum 2013. Bandung: Remaja Rosdakarya.

Nuruzzaman, M. 2015. Faktor-faktor yang Menghambat Implementasi Kurikulum 2013 di SMKN 1 Seyegan Sleman Jurusan Teknik Gambar Bangunan (TGB). Skripsi. UNY. Yogyakarta.

Sugiyono, 2008. Metode Penelitian: Pendekatan Kualitatif, Kuantitatif dan $R \& D$. Bandung: Alfa Beta

Undang-undang Nomor 2 Tahun 1989 Tentang Sistem Pendidikan Nasional. (Lembar Negara RI Tahun 1989, Tambahan Lembaran Negara Republik Indonesia Nomor 3390).

Undang-undang Nomor 20 Tahun 2003 Tentang Sistem pendidikan Nasional. (Lembar Negara RI Tahun 2003 No. 78, Tambahan Lembar Negara RI No. 4301).

\section{PROFIL SINGKAT}

Rosa Murwindra, S.Pd M.Si lahir di Desa Sikakak, Kecamatan Cerenti, Kabupaten Kuantan Singingi pada tanggal 14 Juli 1985 yang merupakan anak kedua dari empat bersaudara dari pasangan yang berbahagia Bapak Munardi M dan Ibu Indrayati.

Pada Tahun Akademis 2003/2004 secara resmi melalui jalur SPMB penulis diterima sebagai mahasiswa di Fakultas Keguruan dan Ilmu Pendidikan UR (Universitas Riau) jurusan Pendidikan Kimia. Untuk menyelesaikan studi S1 penulis melaksanakan penelitian dengan judul "Efek Termik Terhadap Stabilitas Zat Warna dari Kulit Buah Jengkol" dan lulus tahun 2008. Pada tahun 2010 penulis melanjutkan studi kembali di Fakultas Matematika dan Ilmu 
Rosa Murwindra, Nofri Yuhelman, Dwi Putri M.

Pengetahuan Alam (FMIPA) UR dan lulus tahun 2013 dengan judul tesis "Studi Pendahuluan Produksi Asam Levulinat dari Inulin Umbi Dahlia (Dahlia sp. L)
Menggunakan Katalis Asam Klorida". Dari tahun 2013 sampai saat ini penulis aktif sebagai dosen pengajar di Universitas Islam Kuantan Singingi (UNIKS 